\title{
Application of Project Management in the Management of Teaching and Research Projects in University
}

\author{
Jun-hang Ding* \\ College of automation \\ Qingdao University \\ Qingdao, Shandong, China
}

\author{
Hai-sheng $\mathrm{Yu}$ \\ College of automation \\ Qingdao University \\ Qingdao, Shandong, China
}

\author{
Min Li \\ Dean's office \\ Qingdao University \\ Qingdao, Shandong, China
}

\begin{abstract}
The project of teaching and research in university is an important link to deepen the reform of education and teaching, strengthen the teaching level of schools and improve the competitiveness of schools. To strengthen the process management of teaching and research projects and apply the knowledge system and technical tools in project management to the process of project practice is helpful for the project to effectively improve the project efficiency and ensure the results and quality of the project research in the process of topic selection, project approval, implementation and conclusion. This paper analyzes the problems and shortcomings in the process of teaching and research project management, makes use of project combination thinking, improves the management process, strengthens the supervision and management of the project process, and promotes the transformation of project results, so as to improve the success rate of project establishment and ensure the smooth implementation and quality of the project, and improve the output and application of the project results.
\end{abstract}

Keywords - teaching and research project; project management; management process optimization; project combination thinking; project process supervision

\section{INTRODUCTION}

In recent years, project management is widely used in engineering, military and other types of project management concepts, and gets scientific certification in practical application. The project management knowledge system was proposed by the American Association for Project Management (PMI) in the late 1970s. It is to take the project life cycle as the main line to manage each stage of the project. Projects are divided into start-up, planning, implementation and closing phases. The knowledge involved in each phase

Fund project information: Education service new and old energy conversion professional docking industry project (automation professional group, Shandong Provincial Department of education, 2018); teaching reform project of Qingdao University ("reform research practice of automation professional training mode and mechanism in the era of Intelligent Manufacturing", "research and practice of automation professional transformation and upgrading", 2017) includes: integrated management, scope management, time management, cost management, quality management, human resources management, communication management, risk management, procurement management, stakeholder management and other specific management knowledge [1].

The teaching and research project in University is a series of researches focusing on the new phenomena and problems in teaching activities. And the final results of the research will be applied to guide teaching, and then promote the smooth development of teaching activities.

Teaching and research project in University have their own characteristics in addition to temporary and unique characteristics. Mainly in the following aspects:

\section{1) Innovation and exploration}

Teaching and research project in University is a series of exploratory and innovative activities according to the requirements of the latest technological progress at home and abroad and national strategic deployment. The project focuses on the cultivation of innovative, compound and applied talents to meet the needs of the society, runs the innovation and entrepreneurship education throughout the whole process of talent cultivation, improves the curriculum system, strengthens the construction of teaching materials and training bases, and encourages teachers to innovate teaching methods.

\section{2) Technology frontier}

The teaching and research project in University is a research on deepening education reform based on the latest technology development trend at home and abroad and the latest national strategic policy, and it is a continuous work to meet the national development needs. So in the whole project research, we need to contact the latest technology and policy, and need to study, research, extract and apply all kinds of knowledge and fields in depth. 


\section{3) Uncertainty}

Due to the characteristics of innovation, exploration and technology frontier, teaching and research project has high risk and uncertainty.

In the whole life cycle of the teaching and research project, the project management knowledge system and tools are used to manage and supervise the project. And in view of the problems existing in the management of teaching and research projects, this paper puts forward targeted solutions and optimization measures.

\section{MAIN PROBLEMS IN THE MANAGEMENT OF TEACHING AND RESEARCH PROJECTS IN UNIVERSITY}

\section{A. Lack of Unified Management}

Teaching and research projects are mainly divided into national projects, provincial and ministerial level projects and school level projects. And each kind of project subject type, subject difficulty, implementation cycle, project scale have obvious difference. In the past project management process, teaching and research projects are generally regarded as independent projects. They are singly managed and controlled. The lack of management concept of project portfolio and project set is easy to cause the waste of project resources, the lack of relevance between projects and the lack of value of project achievements.

\section{B. Insufficient Construction of Project Process}

University pay more attention to the number of projects in teaching research reform [2], and take the number of projects as the performance evaluation index. However, the supervision and management of project research quality and results promotion is relatively loose, which leads to the project not being implemented in accordance with the project objectives and quality requirements during the implementation process, and at the same time, the project research results are ignored to be timely transformed and put into the actual teaching.

\section{Inadequate Supervision of the Project Process}

Because the project does not have detailed project implementation plan, project quality standard and delivery responsibility system in the project application materials, there is no corresponding basis to supervise the implementation of the project in the process of project implementation. This leads to the problems of project progress delay, budget overrun, poor quality of research results and so on.

\section{Insufficient Social Benefits of Project Outcomes}

In the actual promotion process of project achievements, due to the insufficient promotion efforts, unclear promotion objectives and imperfect promotion methods and strategies, the project evaluation feedback lags behind, and the social benefits of the project are insufficient. Finally, the result of teaching and research project is not timely, which affects the important role of teaching and research project in improving teaching quality [3]-[4].

\section{IMPROVEMENT MEASURES ON MANAGEMENT OF TEACHING AND RESEARCH PROJECTS}

According to the characteristics and existing problems of teaching and research project management in University, we can optimize the project management framework, optimize the management process, strengthen the process management and strengthen the project achievements promotion and other measures. Promote the whole research process of the project to be more standardized and efficient.

\section{A. Project Management with Project Portfolio and Project Set}

In project management, project portfolio refers to the centralized management of multiple projects in order to achieve strategic objectives, and project set refers to the management of multiple interrelated projects [1]

In the management of teaching and research projects in university, the project can be classified into the same type of project portfolio and project concentration through the characteristics of project category, project reform direction and project research content. As a project, it can be managed in three different modes: separate projects, components of the project set, or components of the project portfolio.

Through the use of project portfolio and project set management, we can integrate multiple related and continuous projects and realize periodic management. Using the project management framework can optimize the overall planning of project resources from a high level, and deal with related problems and risks under the same governance framework. We also achieve the benefits of each project by effectively analyzing, sequencing, and monitoring the dependencies between projects.

\section{B. Optimize Project Management Processes}

According to the whole life cycle concept defined by PMI, the teaching and research projects are divided into project demonstration stage, declaration stage, project implementation stage, project acceptance stage and project achievement promotion stage [5]. Each stage carries out effective execution management according to the method of knowledge field in project management and the characteristics of the project itself. Refer to figure 1 for specific stages and related work.

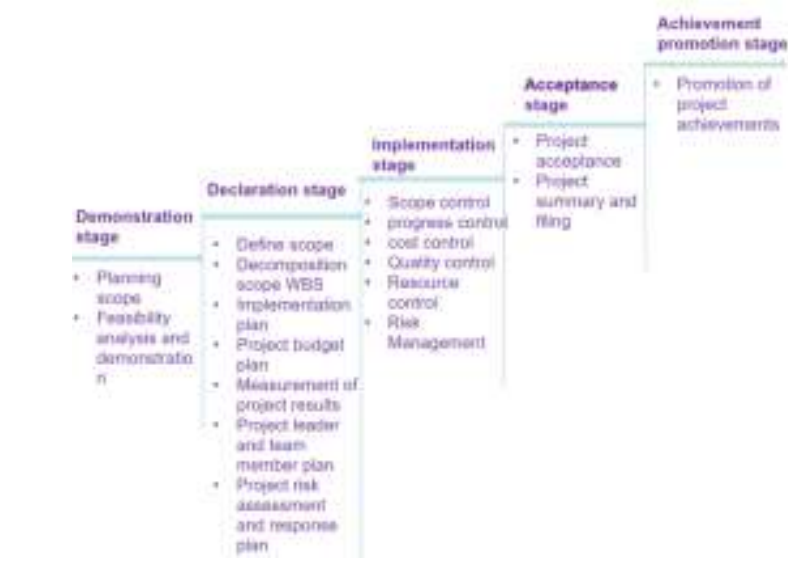

Fig. 1. Project Management Processes 
The project demonstration stage is mainly to plan the project scope and analyze the feasibility of the project. In order to improve the passing rate of the project, the business demonstration and benefit analysis methods in the project management can be used. Systematic analysis of the project objectives, benefits, strategic consistency, from the internal and external aspects of the mining project research significance.

Project declaration stage is an important work in the project process. In order to make the project application successful and improve the bid winning rate, researchers need to pay attention to the writing of the project application. In the application form, the project research content, project implementation plan, project budget plan, project resource allocation and project quality evaluation index shall be explained in detail.

After the project application is passed, the project enters the implementation stage. In order to ensure that the project runs on the planned track, it is necessary to strengthen the supervision and management of the project implementation process. Through the use of important node review, milestone review, performance evaluation and other methods in project management, the monitoring of the project can effectively avoid the problems of process management irregularities, project objectives deviation, project funds exceeding the standard, project delay and so on.

In the project acceptance stage, the project leader should do a good job of project acceptance and summary and filing of the project in time. Provide valuable experience guidance for the smooth development of the project in the future.

In the project achievement promotion stage, through the tracking management of the later stage of the project, actively organize the teaching reform achievement report meeting and experience exchange meeting to actively promote the application and promotion of the reform achievements.

\section{Strengthen Project Process Supervision}

In order to ensure that the project runs on the planned track, it is necessary to strengthen the supervision and management of the project implementation process [6].

\section{1) Important node review}

Schedule management is an important part of project management. When the project is planned, the project leader should organize the relevant departments and experts to check and review the project at the important node. The purpose of node inspection is to evaluate the progress, results and quality of the project, and to urge and solve the problems found in the evaluation process

\section{2) Milestone review}

Milestone review is a very effective management method. Through milestone review, we can determine whether the objectives of this stage have been achieved, and review the scheme of the next stage to determine whether we can enter the next stage. Ensure that the project is carried out according to the plan to avoid major deviation.

\section{3) Project Performance Analysis}

In the process of project implementation, regular performance analysis is needed. Generally, the analysis content includes the project progress, implementation, cost usage and forecast of future situation. According to the length of the project cycle, the analysis cycle is generally conducted on a monthly basis. Methods and tools frequently used include earned value analysis, deviation analysis, trend analysis, etc [7].

\section{Strengthening Management Project Knowledge}

When the project enters the final acceptance stage, The project leader needs to do the acceptance and summary work in time.

\section{1) Project acceptance}

When the project meets the expected objectives as planned the project leader should carry out the project acceptance work in time. According to the conclusion process of the project, the review experts identify and accept the implementation process data, research results, innovation content, project cost and expenditure details of the project.

\section{2) Project summary work}

After the acceptance of the project, the project leader should file the process documents and target results of the project in time, and also organize the project team to carry out the project summary meeting. And make a comprehensive analysis and summary from the project research process, progress, scope, quality, cost, personal gain, team cooperation and so on, and put the lessons of the project into the knowledge base of project experience and lessons, which provides valuable experience guidance for the smooth development of the future project.

\section{E. Enhanced Dissemination of Project Results}

The ultimate goal of the teaching and research project in university is to improve the quality of school teaching and improve the cultivation quality of students through the research results. Therefore, it is very important to popularize and apply the achievements of teaching and research projects.

1) Change the Thought of "Emphasis on Research, Less Application"

In the process of the management of educational reform research projects in university, it is necessary to change the thought of "emphasizing research and neglecting application" [5]. In the evaluation system of performance evaluation, the practical value and promotion degree of project achievements are regarded as an important evaluation index.

And through the follow-up management of the later stage of the project, actively organize the teaching and research project results report meeting, experience exchange meeting, etc. to actively promote the application and promotion of the reform results in a "point to area" way. To improve the enthusiasm and initiative of researchers, we should pay more attention to the promotion of project achievements, so as to change the thinking mode of scientific research which only focuses on publishing papers and appraising awards. 
2) Establishment of a dedicated results outreach organization

Set up a special organization to promote the achievements of teaching and research projects. The promotion and application of teaching and research achievements in university are deeply studied by professional staff. It explores a set of effective new mechanism, new mode, new measures and new methods for the promotion and application of the project results of educational reform. To provide methodological guidance for the popularization and application of the project results of the teaching reform in university [8]. So as to solve the problems of insufficient promotion of teaching and research reform project results, unclear promotion objectives and imperfect promotion methods and strategies.

\section{CONCLUSION}

As an effective management method, project management has been verified in various industries, which fully shows its feasibility and scientific nature. In the teaching and research projects of university, strengthening project management is conducive to giving full play to the advantages of university, ensuring the correct direction and practical pertinence of teaching research, and promoting the output and application of excellent teaching achievements. University should further strengthen the unified project management, improve the project management process, pay attention to the supervision and management of the project implementation stage, strengthen the demonstration and promotion of the project results and other measures to effectively play the important role of the education reform project in improving the quality of personnel training.

\section{REFERENCES}

[1] Project Management Institute, Guide to Project Management Knowledge Systems (6th Edition), Publishing House of Electronics Industry, 2017 (I):1-228. (In Chinese).

[2] Wang Lan and Liu Xiaofeng, "Application of Project Management in Research Project Management of Research Institute”, Management Watch ,2015(2):176-177. (In Chinese).

[3] Chen Beibei and Zhang Yixiao, "Thoughts on Strengthening the Project Management of Teaching Reform in University", Science and Education Guide ,2018(6):27-29. (In Chinese).

[4] Luo Zhuhua, "A Study on Improving the Management Efficiency of Teaching Reform Project in Local Colleges and Universities", Modern Educational Science ,2019(12),34-37. (In Chinese).

[5] Peng Wenhui and Yu Huapeng, "Analysis on the Management of the Whole Process Elements of College Projects from the Perspective of Standardization Evaluation", New Industrialization ,2018(8):83-88. (In Chinese).

[6] Zheng Xiaochuan and Hu Xiaoqing, "A Preliminary Study on the Whole Process Management of the Teaching Reform Project in University ", New Curriculum ,2013(8):83-84. (In Chinese).

[7] Luo Tao, "Application of Project Management Method in the Performance Management of Scientific Research in University", Green Technology ,2019(21):249-250. (In Chinese).

[8] Ge Xiaohan, "Discussion on the Optimal Measures of Educational Reform Project Management in University", Contemporary Educational Practice and Teaching Research (Electronic Journal),2018(11):560. (In Chinese). 